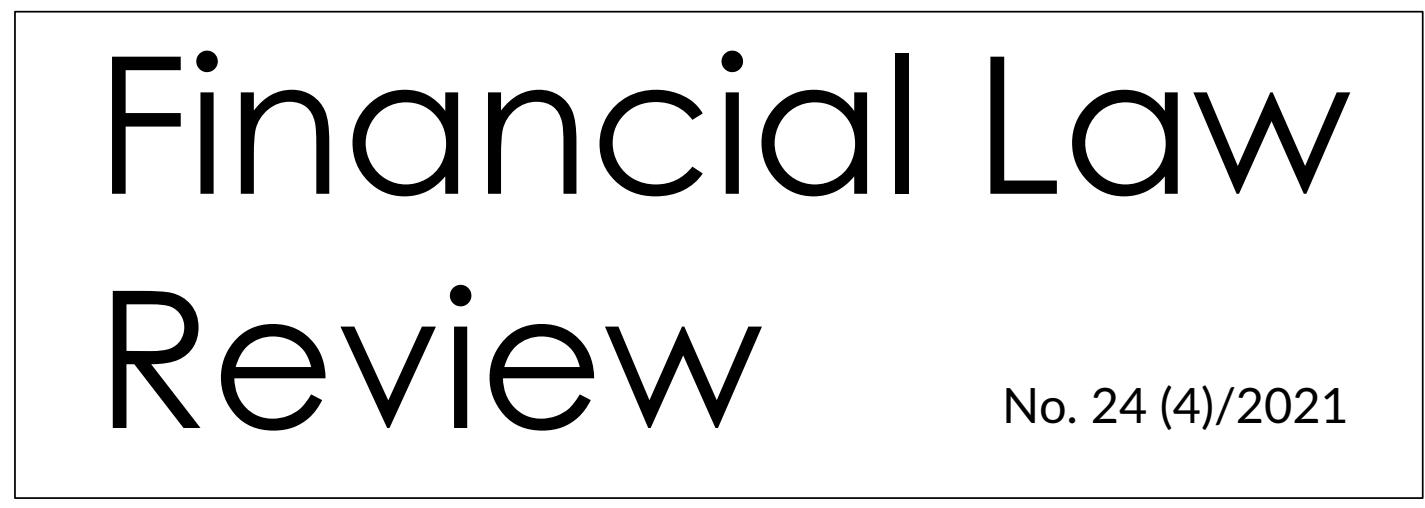

UNIVERSITY OF GDAŃSK • MASARYK UNIVERSITY • PAVEL JOZEF ŠAFÁRIK UNIVERSITY • UNIVERSITY OF VORONEZH

http://www.ejournals.eu/FLR

RAFAt MROCZKOWSKI*

\title{
LEGAL EFFECTS OF UNENFORCEABILITY OR INVALIDITY OF AN AGREEMENT FOR A DENOMINATED IN OR INDEXED TO A FOREIGN CURRENCY MORTGAGE LOAN IN THE LIGHT OF JUDICIAL DECISIONS
}

\begin{abstract}
An introduction of mortgage currency loans to the banks offers, particularly the indexed to a foreign currency and denominated in a foreign currency loans, based on agreements containing abusive clauses which lead, in the consumer/borrower's individual relations, to the violation of his legal and economic interest and on the financial system level to the creation the risk of its instability (systemic risk).

In many European countries, in Hungary for instance, the problem was solved ex post on the statutory level by the legislator's interference. In others, for example in Romania, such statutory solutions were contested by the constitutional courts. In the remaining ones, such as Poland, Spain or Austria, the problem was left to be solved within the individual cases by the civil or arbitration courts. The latter solution requires however the development of lines of jurisprudence solving the contentious legal issues resulting from the complicated legal relations that occurred between the banks and the consumers/borrowers. Given the above, the author undertook to analyse the judicial
\end{abstract}

* PhD, assistant professor at the Department of Financial Law at the Faculty of Law and Administration of the University of Gdańsk. An academic teacher since 2004. Editorial secretary of the scientific journal Financial Law Review. Author of over 80 publications in the field of financial law, financial markets law, including banking law and capital market law; coach; attorney-at-law specializing in cooperative banking services. Privately - a happy husband and a father of four children.

Contact e-mail: rafal.mroczkowski@ug.edu.pl; ORCID: https://orcid.org/0000-0002-7919-3751. 
decisions of the European Court of Justice, Polish common courts and the Supreme Court in order to indicate these nodal issues which often evoke the discrepancies in jurisprudence, as well as to present the possible solutions. The importance of the issue is crucial not only to the economic condition of the households and financial results of particular banks, but also to the stability of the whole financial sector.

The implementation of the research goal adopted in this article requires the application of legal research methods, such as in particular the general theoretical method and the formal-dogmatic method.

Key words: mortgages, banks, banking law, financial system.

JEL Classification: G21

\section{Introduction}

In the socio-economic system of every modern state, housing performs not only economic functions but above all it is a public good. In terms of the former function, housing is an investment asset, being usually the main element of household wealth. It might also be a subject of both individual and institutional investment ${ }^{1}$. Housing as a public good serves to fulfil people's fundamental needs related to providing shelter - so called "roof over one's head". It is meant to be a material foundation of a family, enabling it to set up and run an independent household and also creating a feeling of security and life stability.

Due to the reasons presented above, ensuring the decent housing is treated as one of the fundamental human needs and obviously it is a basis for making a decision to set up a family which is the fundamental group unit of society and is entitled to protection by the State [Constitution of the Republic of Poland, Art. 18]. The State, in its social and economic policy, is obliged to take into account the good of the family [Constitution of the Republic of Poland, Art. 71]. It is expressed in a particular way in Art. $75 \S 1$ of the Constitution according to which public authorities have an obligation to pursue policies conducive to satisfying the housing needs of citizens, in particular supporting activities aimed at acquisition of a home by each citizen. Therefore, the state is bound, through regulatory actions as well as financial and organizational support, to pursue such housing policies which enable families to fulfil their housing needs ${ }^{2}$.

\footnotetext{
${ }^{1}$ The dynamic development of the institutional rental market (Private Rented Sector- PRS) began in Poland only in 2019 and the process is expected to accelerate in the upcoming years [Bojęć et al. 2020: 59].

2 Currently, the basic document stating the Polish housing policy is the National Housing Programme [The Council of Ministers 2016].
} 
In relation to the current housing situation in Poland, it must be pointed that the housing policy of the Polish State conducted in Poland after the political transformation occurred to be partially ineffective. Admittedly, due to the growing supply of new dwellings in the recent years, the housing deficit in Poland is being reduced [Napiórkowska-Baryła et al. 2026: 109; Makowska 2013: 126-142], but according to various sources still ranges from 650 thousand [Ministry of Development 2020: 13] to 2,1 million [Heritage Real Estate Think Tank 2018: 39] dwellings. This is further supported by such indicators as: the number of dwellings per 1000 inhabitants, the average usable floor area of a dwelling or the number of persons per 1 dwelling, which still remain one of the worst in the EU [Ministry of Development 2020: 12-14].

In view of this, the state policy in the field of currency mortgage loans should be judged particularly negatively. The peak of their popularity in Poland was in the time of housing boom in the years 2005-2007. Unprecedented increase in demand for property and their prices, as well as the accompanying increased interest in mortgages was related to the improvement of economic situation and the growth of the population's income and employment rates. Banks in Poland responded to that phenomenon with an introduction to their offers of denominated in a foreign currency mortgage loans ${ }^{3}$ and indexed to a foreign currency mortgage loans (so called currency mortgage loans) ${ }^{4}$. From the time perspective, it needs to be estimated that in the analysed period the Polish state failed not only in the area of the regulatory policy due to the abandonment of actions leading to introduction of appropriate legal framework for the currency mortgage loans, but also in the area of the supervisory policy due to refraining from introducing adequate recommendations for banks, as well as abandonment of any other supervisory actions directed at mitigation of the currency risk which is an immanent characteristic of such mortgage loans.

Meanwhile, as a result of the noted rapid depreciation of PLN in the years 2008-2015 in relation to the most popular currencies, in which the mortgage loans were denominated or indexed to (CHF and EUR), the described above risk fully materialized. At the beginning it hit the economic interest of the loaners by raising the loan service costs as well as the value of the credit balance after conversion to PLN. At first, mortgage lenders were not

\footnotetext{
${ }^{3}$ More on the subject of the legal construction of denominated in a foreign currency mortgage loans - Mroczkowski 2017: 370-373.

${ }^{4}$ At that time the most important barrier limiting the creditworthiness of the potential buyers were high interest rates on the domestic financial market, which overstated the interest instalments of the mortgage loans granted in PLN. A chance to overcome that barrier was the disparity in the interest market rates in Poland and in the Eurozone and Switzerland. Banks in Poland noticed benefits from including the denominated in or indexed to a foreign currency loans to their offers. Growing popularity of such loans coincided with the significant strengthening of PLN to foreign currencies which considerably increased the risk level [Financial Stability Committee 2017].
} 
directly affected by the situation since the proportion of the currency mortgage loans with delayed repayments was low in relation to the total portfolio. Therefore, banks were not interested in finding any solutions to the problem of the currency loans, leaving their customers on their own with all the consequences of the materialisation of the currency risk. The Polish state, unlike Hungary or Croatia, was also idle in the matter and despite numerous legislative initiatives and regulatory actions taken up in the years 2015-2020 had not introduced any effective legislative or supervisory instruments which would lead to the general solution of the growing problem of the currency loans. The situation described above took place in spite of the fact that as early as in 2016 the Financial Stability Committee, as a competent authority responsible for the macroprudential supervision, indicated that "the currency loans portfolio was a source of systemic risk" [Financial Stability Committee 2016]. Moreover, in the following year, the same authority stated that as a result of the ongoing materialisation of the foreign exchange risk, the risk would continue to grow and might become a catalyst of the banking crisis in Poland [Financial Stability Committee 2017].

In response to the lack of effective actions undertaken by the state bodies, the continuously growing number of borrowers decided to initiate court proceedings against the lenders. After 2015, judgements concerning the currency loans were given more and more often by common courts and then by the Supreme Court. In the initial stage, due to the high level of complexity of the financial relations between the parties, a judicial chaos occurred which manifested itself with huge discrepancies in the jurisprudence of the common courts. An extreme example of it was the situation when different courts came to contradictory decisions, either in favour or against the borrowers, in cases based on the analogical construction of the currency loans, often even based on the same loan agreement. When the Court of Justice of the EU gave a ruling in the matter of the consequences of the use of abusive clauses in favour of the borrowers on 3 October 2019 [C-260/18], a clear change in the line of jurisprudence could be observed. Since February 2020 more than $90 \%$ of the litigations concerning currency mortgage loans were won by the borrowers [Votum Robin Lawyers Legal Office 2020]. This in turn caused the change of the vector direction of the materialised currency risk which now strikes the banks with increasing force in direct proportion to the growing number of the cases brought to the courts by the borrowers. It was not until Polish Supreme Court (hereinafter also: PSC) scheduled to hold a sitting of the civil chamber in its full line-up on 23 March 2021, which meant a real threat to the banks that the adverse for them line of jurisprudence would be 
unified by the Supreme Court ruling which has the power of the legal principle ${ }^{5}$, when the banks were compelled to start the cooperation with the Polish Financial Supervision Authority in order to create a solution based on the proposal of the Chair of the Board of the Polish Financial Supervision Authority Jacek Jastrzębski in terms of concluding settlement agreements with the borrowers [Polish Financial Supervision Authority suggests banks concluding settlments concerning the CHF loans]. The first tangible effect of the aforementioned cooperation was the initiation of the CHF-settlement programme by PKO BP S.A. on 4 October 2021 which aims at concluding settlements with the consumers who have mortgage currency loans [PKO BP start a Swiss-Franc Settlement Programme].

The aim of this article is to indicate and analyse the key problems causing discrepancies in the judicial decisions of the common courts in cases concerning currency mortgage loans. The importance of the issue is crucial not only to the economic condition of the households and financial results of particular banks, but also to the stability of the whole financial sector.

The implementation of the research goal adopted in this article requires the application of legal research methods, such as in particular the general theoretical method and the formal-dogmatic method.

\section{Unenforceablility of the abusive clauses in an agreement for a denominated in or indexed to a foreign currency mortgage loan and their invalidity}

Denominated in or indexed to a foreign currency mortgage loan agreements contain currency clauses. "Their function consists in establishing the rules of conversion of the loan amount from the settlement currency (CHF, EUR) to the payment currency (PLN) due to the loan disbursement, but also in the opposite way during the repayment of principalinterest instalments in the national currency but expressed in the foreign currency"6. Without going into details which are unnecessary from the point of view of the aim of this article, it must be stated that typical currency clauses, widely used in such agreements in the years 2005-2008, due to their construction oftentimes turned out to be abusive. The use of such provisions violated the prohibition, expressed in Art. 23a of the Act of 16

\footnotetext{
${ }^{5}$ The case is run upon an application of the First President of the Supreme Court in Poland dr hab. Małgorzata Manowska made on 29 January 2021, signature BSA-I-4110-4/20. The case is still pending while this article is being written.

${ }^{6}$ More on the subject of currency clauses and the grounds to recognise them as illicit contractual provisions (abusive clauses) - Mroczkowski, 2017: 373 - 383.
} 
February 2007 on Competition and Consumer Protection, of the use of illicit contractual provisions in the templates of agreements concluded with consumers which are set forth in the Art. $385^{1} \S 1$ of the Civil Code. According the aforementioned rule, provisions of a concluded agreement are not binding for a consumer if they were not individually negotiated with the consumer, framing the consumer's rights and obligations in a manner contrary to good practice and grossly infringing the interests of the consumer. Recognition of currency clauses as illicit contractual provisions is a basis of the use of sanction of unenforceability.

Regardless of the above, a lot of agreements concluded in the years 2005-2008 in view of Art. $58 \S 1$ of the Civil Code with reference to Art. $69 \S 1$ and 2 of the Banking Law, the jurisprudence and views presented in the doctrine may be recognised as entirely invalid if the agreements did not contain all the construction elements being essentialia negotii of a bank loan agreement. In this context it must be pointed out, without going into details, that an agreement which, on the day of conclusion, does not allow to quantify precisely the loan amount or contains abusive currency clauses which may give rise to differences between the declarative, actually disbursed and the repaid loan amount cannot be recognised as a loan agreement in the understanding of Art. 69 of Banking Law.

The declaration of unenforceability of the provisions of a currency mortgage loan agreement or the declaration of its invalidity leads to the collapse of the agreement and the mutual considerations, which were fulfilled due to the conclusion of the agreement, are treated as not due. In such situation, based on the Art. $410 \S 1$ with reference to Art. 405 of the Civil Code both parties are entitled to claim a return of any a performance carried out in performance of that agreement, i. e. the borrower - the return of the amount of the paid commission and principal-interest instalments, and the bank - the return of the amount of the disbursed loan. However, the effectiveness of such claims needs to be additionally considered in the view of the provisions on limitation period and their mutual relationship in the light of the two competing theories: theory of unjust enrichment and theory of balance. Additionally banks lodge claims against the borrowers concerning the remuneration for using the their capital.

Based on the explanation of the previously mentioned rules a few nodal legal problems arose which cause discrepancies in the judicial decisions of the Supreme Court and the common courts. In respect to that the First President of the Supreme Court Matgorzata Manowska, acting under Art. $83 \S 1$ of the Act on the Supreme Court on 29 January 2021 made an application for the resolution through the meeting of the entire composition of the Civil Chamber of the Supreme Court of the following legal issues: 
1. In the case of concluding that the provision of an indexed or denominated loan agreement that concerns determining the exchange rate of the foreign currency is unlawful and does not bind the consumer, is it possible to assume that this provision is replaced by another method of determining the exchange rate of the foreign currency that follows from legal regulations or custom? in case of a negative answer;

2. In the case of it being impossible to determine the foreign currency exchange rate binding the parties in a loan agreement indexed to that currency, can the agreement bind the parties in all other aspects?

3. In the case of it being impossible to determine the foreign currency exchange rate binding the parties in a loan agreement denominated in that currency, can the agreement bind the parties in all other aspects? regardless of the answers to the questions 1-3:

4. In the case of an invalid or ineffective loan agreement, in performance of which the bank disbursed to the borrower all or some of the loan amount and the borrower is repaying the loan, do separate claims on account of undue performance arise for both parties, or is there only one claim, equal to the difference between the performances carried out to the benefit of the party whose total performance was of higher value?

5. In the case of the loan agreement being invalid or unenforceable due to the unlawfulness of some of its provisions, does the prescription period for the bank's claim for the return of the amount disbursed on account of the loan commence at the moment of disbursement?

6. In the case of the loan agreement being invalid or unenforceable and any of the parties having a claim for the return of a performance carried out in performance of that agreement, does that party may also demand a remuneration on account of the other party using its funds?

These issues are to be adjudicated by the Civil Chamber of the Supreme Court in the course of the ongoing proceeding. It is worth mentioning that the above questions partially overlap the five preliminary questions of the District Court (hereinafter: also DC) in Gdańsk, in the subject of which the ECJ on 29 April 2021 gave its judgement in the case C$19 / 20$ as well as four questions of the Financial Ombudsman which were resolved by the Supreme Court in its resolution delivered by 7 judges on 7 May 2021 in the case III CZP $6 / 21$. 
In the following part of the article the author conducted a legal analysis of the above mentioned problems in the light of the current judicial decisions, being aware that the presented theses may deviate from the explanation adopted by the Supreme Court in the expected resolution to be given at the request made on 29 January 2021.

\section{Acceptability of a different way of determining the foreign currency exchange rate in case of concluding that the conversion clause is unenforceable}

In that context It needs to be stated that the ECJ in its decisions time and again, firmly spoke against any attempts leading to fill the gap caused by making the unfair clause unenforceable, particularly against the concept of so-called reduction preserving effectiveness. In its judicial decisions the ECJ stresses that in case the agreement continues to exist, it is impossible to change its content and which also stands against the Art. $6 \S 1$ of the directive on unfair terms in consumer contracts. The justification for the negative approach for such solution is the penal character of the sanction of partial unenforceability which is designed to deter the unfair professional trading participants from using the abusive clauses. In case it was possible to eliminate any abusive clause without any negative consequences for the user of the agreement template, the rule of the directive 93/13 would not prevent anybody to use the illicit contractual provisions [ECJ C-618/10; ECJ C-488/11; ECJ C-118/17]. The ECJ developed this thesis in its judgement in Dziubak case stating beyond any doubts that "Art. $6 \S 1$ of the directive 93/13 must be interpreted as precluding gaps in a contract caused by the removal of the unfair terms contained in that contract from being filled solely on the basis of national provisions of a general nature which provide that the effects expressed in a legal transaction are to be supplemented, inter alia, by the effects arising from the principle of equity or from established customs, which are neither supplementary provisions nor provisions applicable where the parties to the contract so agree". Such standpoint was confirmed also in the jurisprudence of the Supreme Court [PSC II CSK 632/17].

In view of the currently binding regulations of the European law and ECJ judiciary decisions, the admissibility of modification of the agreement by the court so that after removal of the unfair clauses it will be completed on the basis of hypothetical will of the parties, general law or established customs, which will ensure the further existence of the agreement in a modified form. Therefore, it is not possible for the court to arrange a correct exchange rate in place of the abusive currency clauses removed, such as applying the central bank's average rate. 


\section{The effects of the lack of possibility to determine the exchange rate binding on both parties in a foreign currency indexed mortgage loan agreement}

Due to the construction of a foreign currency indexed loan agreement, the loan amount is determined in the agreement in the national currency, in which the loan is also disbursed and only secondarily settled in a foreign currency. This implies that, the loan amount expressed in PLN is converted to the foreign currency on the day of the loan disbursement. The amount determined in such a way and expressed in the settlement currency comprises the sum from which the interest is charged at the rate applicable to that currency. Simultaneously, it is assumed to be the amount which the borrower is obliged to repay with principal-interest instalments expressed in PLN which in turn are converted to the foreign currency solely for settlement purposes.

The removal of the abusive clauses from such construction, in a situation in which they could not be replaced with other methods of determining the exchange rate of the foreign currency to the national one, has the effect that the currency loan becomes a PLN loan, applying to it the interest rate determined on the basis of the LIBOR (CHF or EUR). Such construction is informally called "de-franking" of the agreement.

In order to assess the effects of the claim of abusiveness of the currency clauses for the whole agreement, it is therefore necessary to interpret Art. $385^{1} \S 1$ and Art. $58 \S 1$ of the Civil Code with reference to the jurisprudence of the ECJ. The European Court of Justice obliges a national court to assess the impact of concluding the unfair nature of the contentious contractual provisions on the validity of given agreement and to determine whether the agreement at issue may continue in existence without such assessment.

Contractual provisions which were considered abusive are not binding on the consumer [Art. $385^{1} \S 1$ of the Civil Code] Moreover, pursuant to Art. $385^{1} \S 2$ recognition of a given term as non-binding [unenforceable] does not affect the rest of the agreement which shall continue to bind the parties. Analogically, in case of conclusion of the contractual provisions being contrary to the mandatory law stipulated in Art. $58 \S 1$ of the Civil Code, in view of the aforementioned article only part of the legal action is considered invalid, the action shall remain in force as far as other parts of it are concerned, unless due to given circumstances the action would not be fulfilled without the invalid terms. The sanction of partial unenforceability or partial invalidity results from the favor contractus principle and the principle of proportionality [Grebieniow et al. 2019: 43].

Given that the provision stipulated in Art. $385^{1} \S 1$ of the Civil Code serves the transposition of the directive $93 / 13$ to the Polish law, the explanation of the character of 
the sanction indicated in the provision requires to take into consideration the guidelines of the directive and the judiciary decisions of the European Court of Justice concerning the said directive. Based on the directive 93/13 the legal effects of the application of the unfair contractual term, including the settlement of the performances carried out on the basis of such statement is regulated by Art. $6 \S 1$. Following the provision mentioned above, Member States are to provide that unfair terms used in contracts concluded with consumers by sellers or suppliers shall, as provided for under their national law, not be binding on the consumer and the rest of the contract, if possible, shall remain binding on both parties after removal of the unfair terms. In respect to the above, the European Court of Justice has repeatedly confirmed that, in principle the definition of conditions on which abusive clauses are to be concluded and the effects of such assessment depend on the national law [ECJ C-154/15; ECJ C-19/20] Regardless from the above, while interpreting the aims and the content of the directive 93/13, ECJ formulated several guidelines concerning the features of the sanction which limit the range of the said leeway and must be considered by both the national legislator and the national courts while interpreting the acts.

ECJ explained that Art. 6 para 1. of the directive $93 / 13$ is a mandatory norm and which aim is to substitute for the formal balance established by the agreement between the rights and obligations of the parties real balance re-establishing equality between them [ECJ, C618/10]. According to Art. 6 para. 1 of the directive 93/13/EWG and the settled case-law of the ECJ [ECJ C-618/10; ECJ C-488/11; ECJ C-377/14], the sanction resulting in the non-binding status or invalidity of the abusive clause does not change the fact that the parties remain bound by the other provisions of the loan agreement at issue as long as it does not lose the economic sense and infringe the consumer's interest. Following the ECJ judiciary decisions, it is evident that taking into account the consumer's interest means that he has the right to object to simple conclusion of the clause being unenforceable which indicates that it may not be perceived as ex lege sanction [ECJ C-243/08; ECJ C-472/11; ECJ C-397/11; ECJ C-488/11]. As a result, it is up to the consumer whether in such circumstances the loan agreement in question shall be annulled in its entirety or not [Grebieniow et al. 2019: 44-45]. According to the ECJ jurisprudence, the national court is obliged to take the consumer's will into account if the latter, being aware of the nonbinding status of a given term, indicates that he objects against preclusion of the given term, thus giving his free and informed consent to the term in question [ECJ, C-472/11] In its later decisions, the ECJ has formulated an obligation on the consumer to express his 
"free and informed" consent to uphold the abusive term of the agreement. Obviously, the consumer may also clearly object to the abusive clause being upheld [ECJ C-260/18].

In view of the above, in a situation when the consumer considers that upholding the agreement as a PLN loan, with the interest rate resulting from the agreement and based on the variable LIBOR CHF (de-franking), as unfavourable, may demand the entire agreement be concluded unenforceable which would in turn lead to the annulment of it. Such position was confirmed by the ECJ in the mentioned above judgement of 3 October 2019 in Dziubak case, indicating explicite that "Art. $6 \S 1$ of Council Directive 93/13/EEC on unfair terms in consumer contracts must be interpreted as not precluding a national court, after finding that certain terms of a loan agreement indexed to a foreign currency and subject to an interest rate directly linked to the interbank rate of the currency concerned are unfair, from taking the view, in accordance with its domestic law, that that contract cannot continue in existence without those terms [ECJ C-260/18].

\section{The effects of the lack of possibility to determine the exchange rate in a denominated in a foreign currency mortgage loan agreement}

Due to a different legal construction of an agreement for a denominated in a foreign currency mortgage loan, it is necessary to consider the effects of the lack of possibility to determine a binding on both parties exchange rate for the currency in question. The substance of a denominated loan is connected to the granting of the loan in a currency other than the national currency, whilst disbursing it in PLN after conversion according to the exchange rate which arrangement or level is specified in the agreement. The loan repayment is being carried out in PLN in the amount being equal to a principal-interest instalment expressed in a foreign currency and provided in the repayment schedule. Therefore, the removal of the abusive currency clauses would lead to remaining the construction of a currency loan granted and disbursed in a foreign currency.

However, in case of a loan denominated in a foreign currency - according to the author, it is impossible to apply the principle of contract sustainability and the principle of proportionality stipulated in Art. $385^{1} \S 2$ and Art. $58 \S 3$ of the Civil Code. The analysis of the socio-economic context accompanying the conclusion of such agreements leads to an assumption that without the contentious currency clauses, the action would not be fulfilled since it would be contrary to the will and economic interests of both parties. After removal of the abusive currency clauses from the content of the agreement in question, the said agreement would become, against the will of both parties, and agreement for a currency 
loan, requiring the disbursement of the loan amount in a foreign currency and its repayment by the borrower in the instalments in the same currency. Meanwhile, the intention of typical borrowers is to take out a loan for a purchase of a residential property, located in the borrowers' country, which price provided in the sales contract is expressed in the national currency. Moreover, in the majority of cases, since the source of income of the borrowers is located in Poland, their earnings intended for the repayment of the loan are obtained in the national currency. Therefore, the typical borrowers' will is obtaining a loan disbursed and repaid in PLN. Such is also the intention of a bank which has funds intended for lending in national currency, not in CHF or EUR. According to the intention, will and interests of both parties of the agreement the denominated loan is disbursed and operated in the national currency. Therefore, it is not allowed to uphold the said agreement assuming that the performances of both parties were supposed to be carried out solely in a foreign currency. Not only would it be contrary to will of both parties which was sufficiently expressed and clearly stated in the agreement during its conclusion, but also as a consequence would lead to unfavourable economic effects. It is also impossible to conclude unenforceability of the agreement only partially [excluding the currency clause], because without it the contractual activity would not be performed by the parties - the bank would not conclude the currency loan agreement with the borrower and the borrower would not do it with the bank [Grebieniow et al. 2019: 35-36].

In these circumstances, the only possible consequence of concluding the currency clauses abusive in a denominated in a foreign currency loan agreement is its entire annulment.

\section{Claims of parties in the light of the theory of two condictions and the theory of balance}

Based on the judiciary decisions of the Supreme Court, it is beyond doubt that if a loan agreement occurred unenforceable [invalid], the performances carried out on its basis should be perceived as undue performances within the meaning of Art. $410 \S 2$ of the Civil Code [PSC III CSK 159/17; PSC I CSK 242/18; PSC III CZP 11/20]. The Supreme Court gave also its unambiguous judgement concerning the restitution claims between both parties which cause discrepancies in the jurisprudence. In its judgement of $11^{\text {th }}$ December 2019 the Supreme Court found that the performance carried out by the borrower on the basis of an abusive provision shall be reimbursed in principle, regardless if the borrower was at the same time the bank's debtor. Moreover, the opposite position shall be contrary to the prevailing in the doctrine theory of two conditions [PSC $\vee$ CSK 382/18]. In the 
justification, the court indicated that in Art. $410 \S 1$ of the Civil Code the legislator determined that the sole fulfilment of the undue performance is the source of the claim for return for which the impoverished is entitled and there is no need to establish neither if and to what extent the carried out performance enriched the recipient, nor if due to the performance the property of the impoverished decreased, The sole carrying out of the performance fulfils a premise of the impoverishment of the plaintiff and the reception of the performance by the defendant is a premise of his enrichment [PSC I CSK 66/11; PSC V CSK 372/11; PSC V CSK 362/12; PSC II CSK 517/13; PSC I CSK 798/15; PSC II CSK $541 / 16]$.

The position concerning the claims for the reimbursement of the performance carried out in performance of an invalid agreement [undue performance] was upheld in the resolution of $16^{\text {th }}$ February 2021 in which the Supreme Court unambiguously stated that "a party who repaid a loan in the performance of an invalid credit agreement is entitled to a claim for the repayment of the repaid money as an undue benefit [Article $410 \S 1$ in connection with Article 405 of the Civil Code] regardless of whether and to what extent he is a debtor to the bank for the repayment of the unduly received amount of the loan" [PSC III CZP 11/20]. The claims of the bank and the consumer/borrower for the reimbursement of the cash benefits performed on the basis of an invalid [unenforceable] agreement constitute two independent and autonomous conditions. Their compensation is not automatically done ex lege, but shall be obtained by submitting a declaration of reclaim by any of the parties, pursuant to Art. $498 \S 1$ of the Civil Code.

In the ruling discussed above, the Supreme Court stated also that the counteracting theory of balance was formulated in a foreign doctrine in order to remedy the situation in which the obligation of returning one of the mutual considerations fulfilled in performance of an invalid agreement lapse since they became obsolete and not to simplify - alternately to reclaim - the settlement between the parties or the protect one of them against the effects of premature limitation period for its claim or the effects of insolvency of the other party.

\section{The commencement of the limitation period for the claims of the parties}

One of the key issues that are questionable in the jurisprudence and at the same time particularly important to the determining the scope of claims of the parties of the currency mortgage loans is the limitation period of the claims of the parties, to be more precise the maturity of the claims of the parties from which the limitation period begins. It is necessary 
to point out that in the recent years there has been a change in the line of jurisprudence within the scope of the problem.

When analysing the previous line of jurisprudence formed in the 1990's by the argumentation which starting point was the content of the Art. $120 \S 1$ of Civil Code pursuant to which if whether the claim is due or not depends on taking up a given action by the rightholder, the start of the limitation period should therefore be confined to the point in time when the claim would become due if the rightholder took up a given activity in the earliest possible time. Respectively, in reference to the undue performance - the Supreme Court in its resolution of 6 March 1991 pointed out that the date for discharging a performance obligation is also not defined [Art. 405- 409 and 411 and Art. 455 of the Civil Code] and does not result from the nature of the obligation [PSC III CZP 2/91]. In such situation, the reimbursement of the undue performance shall take place immediately after a call or in case it does not take place - after the due date when such call could be performed if the action was taken up immediately following the fulfilment of the undue performance. Hence the start of the limitation period resulting from an open-ended obligation should begin on the day when the performance should be fulfilled if the creditor called the debtor to satisfy the performance obligation in the earliest possible time. In the circumstances referred to in Art. $120 \S 1$ second sentence of the Civil Code, The starting date of the limitation period for a claim for reimbursement of an undue performance should be determined by "adding to the date of conclusion of the agreement the shortest possible time which is necessary in given circumstances for the creditor to perform a call upon the debtor to perform an obligation and the time which is necessary for the debtor, acting with due diligence, so that he could fulfil the performance by satisfying the obligation" [PSC II CSK 625/08]. Application of such interpretation allowed to objectively define the commencement of the limitation period for a claim for reimbursement of undue performance which was appropriate for the creditor and the debtor and was not dependent on the actual activities of the creditor, especially the due date chosen by him for the debtor to be called upon to fulfil the performance. According to the even more farreaching view expressed in the judiciary decisions of the Supreme Court, a claim for undue performance being such at the moment of its fulfilment, used to become due from that very moment [PSC V CKN 769/00]. This means that in case of a court ruling on the unenforceability or invalidity of the entire agreement, the limitation period for a bank's claim for reimbursement of the loan amount started on the day of the actual disbursement of the loan amount, whereas the limitation period for the borrower's claim for 
reimbursement of the repaid instalments started each time the donation was obtained by the bank [Grebieniow et al. 2019: 36-37].

Additionally, for the justification of the aforementioned thesis it was indicated that the judiciary decision concerning unenforceability or invalidity of abusive clauses or the agreement in its entirety causes an ex lege and ex tunc effects and having only declaratory nature. It is beyond doubt both in the case-law [PSC III CZP 29/17; PSC II CSK 803/16; PSC II CSK 768/14] and in the doctrine [Bednarek 2013: 771-772, 814]. Such statement additionally confirmed the thesis that the claims of the parties for the return of the undue performance become due at the time mentioned, and not after the court has given the ruling on the unenforceability or invalidity of the entire agreement.

A claim for the reimbursement of the undue performance falls under the statute of limitations according to the general rules stipulated in the Art. 118 of the Civil Code [PSC III CRN 289/76]. In case the claims are to connected to running a business, similarly to the possible bank's claim in relation to the borrowers for the return of the disbursed loan amount, the limitation period is three years. At the same time, based on the line of jurisprudence of the Supreme Court presented above and connected to the claim for undue performance, it is necessary to assume that the limitation period of the defendant's claim in relation to creditors would begin at the latest on the day when, immediately after the loan disbursement, the creditor could call upon the borrower to return it. Since the peak of the popularity of the currency mortgage loans was observed in the years 20052008 , in most cases the claims of the banks, in the light of the presented above interpretation, the limitation period could have already passed. It is important because in accordance to Art. $117 \S 21$ of the Civil Code, after the limitation period has passed, one cannot demand the satisfaction of his claim for which he is entitled to against the consumer.

However, acceptance of such interpretation of the provisions concerning the limitation period in relation to the adjudication of litigations related to the currency mortgage loans would lead to giving grossly unfair judgements and striking directly not only at the banks economic interests but also indirectly in the stability of the financial system. Probably this statement, based on the dogmatic method as well as economic analysis of law, lead to the formation of new line of jurisprudence in the years 2019-2021 which balances the interests of the banks and the borrowers to a far greater degree.

The starting point for the argumentation emerging in the new line of jurisprudence is a statement that in case of concluding the presence of abusive clauses in a currency 
mortgage loan agreement in question, the consumer/borrower has the right to make a binding decision as to sanate the said illicit provisions or to accept the consequences of the entire invalidity of the agreement [at the same time objects to being protected against the consequences mentioned through introduction of substitute regulation. Therefore, in the judgement of 11 December 2019 [PSC V CSK, 382/18] and in the ruling of 16 February 2021 [PSC III CZP 11/20], the Supreme Court explained that in principle the limitation period of the claims may start only after making the binding decision in this respect by the consumer/borrower. Only then, it may be accepted that the absence of a legal basis for the performance became definitive and the parties could effectively demand the reimbursement of the undue performance [compare Art. $120 \S 1$ first sentence of the Civil Code]. This means in particular that the consumer/borrower cannot assume that the bank's imitation period for its claim has already passed estimated as in case when the call upon the reimbursement of the loan amount was possible on the day of its disbursement [Art. $120 \S 1$ first sentence of the Civil Code]. Taking this argumentation a step further, the Supreme Court in its resolution of the extended bench of seven judges of 7 May 2021 adopted a legal principle according to which "if the loan agreement cannot be binding without such an ineffective term, the consumer and the creditor shall have separate claims for reimbursement of the amounts disbursed in the performance of this contract [Article $410 \S 1$ in conjunction with Article 405 of the Civil Code]. The creditor may demand reimbursement of the amounts disbursed from the moment the loan agreement has become conclusively ineffective [PSC III CZP 6/21].

Simultaneously, the thesis was developed in the justification where the Supreme Court indicated that the agreement becomes unenforceable as soon as the consumer, provided with objective and comprehensive information about the legal consequences of the undertaken court proceedings, shall demand restitution based on an assumption of the entire and permanent ineffectiveness [invalidity] of the loan agreement. At the same time, the Supreme Court clearly states that the said effect does not occur "if it is not accompanied with a clearly stated declaration of the consumer confirming to have been duly informed". As stated further, "obviously in the course of court proceedings, lack of such declaration may be substituted with the court complying with the information duty, and the consumer upholding his restitution claim - after providing him with due information - shall be tantamount to rejection to confirm the clause and [possibly] to his objection to protect him against the consequences of the entire and permanent ineffectiveness [invalidity] of the contract". As a consequence, in majority of cases the commencement of the limitation period for the claims of the borrower starts at the time 
the court is seized and the plaintiff provided the court with his declaration about being duly informed about the legal effects of the court proceedings.

\section{Remuneration for using the repayable funds within the undue performance}

Particular discrepancies in the doctrine and judiciary decisions are raised by the issue of determination of rules of mutual settlements of the parties of a currency mortgage loan which was affected by the sanction of invalidity or unenforceability and in particular the possibility of demanding remuneration for the capital provided to the other party within the performance of the said agreement [so called remuneration for the non-contractual use of capital]. Lack of uniform line of jurisprudence in that matter is an additional factor of legal risk concerning the currency mortgage loans. On one hand, it evokes uncertainty on the side of consumers related to the scope of claims that banks are entitled to in case of an adjudication of invalidity or unenforceability of an agreement, on the other - on the banks side - it makes it impossible to estimate the costs of realisation of the borrowers' claims and generating a significant individual and systemic risk.

While analysing the judiciary decisions of the common courts and the Supreme Court it is necessary to indicate that within the scope of the discussed problems two contradictory lines of jurisprudence we formed along with their legal justification.

The first one is based on an assumption that there is no legal basis for the bank's claim on the borrower for the payment of remuneration for non-contractual use of capital. The argumentation indicated in the judiciary decisions is based on an opinion that such remuneration based on the variable WIBOR rate, would lead to reactivation of an annulled loan agreement in the scope of interests due to the bank. It was argued that there was no legal basis whatsoever for such bank's claim on the borrower [Administrative Court in Białymstok, I ACa 635/19; DC in Warsaw, XXV C 1669/2016]. It must by pointed in particular that the provisions on the unjust enrichment allow for returning to the bank only the performance fulfilled to the borrower which is solely the disbursed loan amount and not any form of remuneration for the use of capital by the borrower. Moreover, the court has stated that any claims that would lead to nullification of the protective function of the rules on illicit contractual provisions are not allowed, in particular those stipulated in Art. 7 of the directive 93/13. If the bank could continue to gain benefits from an invalid agreement, it would nullify the dissuasive character of the rules stipulated in the directive and the national norms established on its basis. Analogical position was adopted by the 
Regional Court ${ }^{7}$ in Warszawa-Śródmieście in its judgement of $8^{\text {th }}$ October 2019 [I C 985/2017].

In opposition to the above mentioned judiciary decisions, parallely another line of jurisprudence was formed which confirmed the admissibility of the banks claims for remuneration for non-contractual use of capital provided by the mortgage loan disbursement on the basis of invalid or unenforceable agreement by the borrower. In the justification of the judgement of $11^{\text {th }}$ December 2019, the Supreme Court did not preclude the possibility of demanding of a payment for provided capital indicating two legal bases: Art. 405 and the following and Art. 224 and the following of the Civil Code. Simultaneously, the Supreme Court stated that the admission of such claim of the bank would not lead to avoidance of the responsibility by the said entity for introduction of abusive provisions to the agreement, because the amount of the remuneration would be significantly lower than the benefits it was entitled to on the basis of the annulled agreement [PSC V CSK 382/18]. The admissibility of the bank's claim due to unjust enrichment was explicitly confirmed in the judgement of the District Court in Warsaw of 26 March 2019 in the justification of which it was stated that, it can hardly be expected that a borrower/consumer was obliged to return only the capital [DC in Warsaw, II C 485/17]. Due to an essence of the operation of a bank and an essence of the loan agreement, it is obvious that the bank should receive the reimbursement of the capital with the remuneration it is entitled to. An analogical view was expressed in the earlier judgement of the District Court in Warsaw of $18^{\text {th }}$ December 2018 [XXV C 2576/18]. Similarly, the Regional Court in Warszawa-Śródmieście in the judgement of 19 April 2019 has asserted that the fact of using the bank's capital without remuneration in the form of interest and provision may be the basis of enrichment, return of which, as undue, may be demanded by the bank [RC in Warsaw-Śródmieście, VI C 1340/17].

The review of the judiciary decisions presented above leads to a conclusion that in the recent years two utterly different lines of jurisprudence were formed which lead to arising serious doubts concerning the scope of mutual settlements resulting from the annulment of a currency mortgage loan, both on the side of banks and the borrowers. It is a serious enough argument for the Supreme Court to give a judgement as a full bench to repeal the emerged legal uncertainty.

\footnotetext{
${ }^{7}$ Hereinafter also: $\mathrm{RC}$.
} 


\section{Conclusion}

According to the author the short-sighted policy of the banks focused primarily on maximizing the profits and minimizing the losses resulting from granting currency mortgage loans, along with the state's omissions in the field of legislative and supervisory policies (from both the ex ante and ex post perspectives) resulted in creation of a problem that strikes stronger and stronger at the economic interests of the banks which causes significant losses on their side, however in case of the development of the most beneficial to the borrowers line of jurisprudence, it may undermine the stability of the whole financial system in Poland. The prospect of finding a solution to the swollen problem, which is the banks and state attitude described above, has arisen only under pressure from the growing number of litigations in the common courts and the still forming line of jurisprudence. As a confirmation of the thesis it is worth mentioning the continuously growing statistics concerning the number of cases referred to courts on the currency mortgage loans. As of 31 December 2020 banks listed on the Warsaw Stock Exchange were a party in 28,1 thousand cases brought to court by the borrowers. This means an increase of $148 \%$ in relation to situation at the end of 2019 [Kisiel 2021].

The formation of the line of jurisprudence within the range of problems mentioned in this article will be the decisive factor in the level of costs for the banking sector related to the cutting the Gordian knot of currency mortgage loans. As results from the analyses carried out by the Polish Financial Supervision Authority the estimated cost of the solution of the problem presented in the article on the side of the banking sector in Poland is ranging from 234 billion PLN - in case of the annulment of the loan agreements by the courts without the obligation of reimbursement of the capital by the borrowers, through 101,5 billion PLN - in case of the annulment of the agreements with the obligation of the reimbursement of the capital, to 70,5 PLN - in case of the annulment of the loan agreement with the obligation of reimbursement of the capital and the remuneration for using it [UKNF 2021]. In reference to the above, based on the conducted analysis of the judiciary decisions, it must be admitted that the lines of jurisprudence that lead to acquiring excessive and unjust performances at the expense of the other party will most probably be precluded. It is necessary to indicate in particular that the significant risk to the banks of the closing limitation periods, as a result of which the borrowers would not be obliged to return the disbursed capital in the form of the loan amount is decreasing due to the newly emerging line of judiciary decisions in the area of the limitation periods for the claims of the parties. In author's opinion - the arguments for admitting that there are no legal grounds 
whatsoever for the claims of banks against the borrowers for unjustified using the banks' capital are very convincing and will contribute to adjudicating a resolution by the Supreme Court confirming the inadmissibility of such claims and giving it the power of the legal principle. This in turn, will strengthen the position of the consumers/borrowers providing them with protection against the unjustified claims of the banks. In particular cases it will return the contractual balance which was disturbed by the use of abusive clauses by banks and will ensure just settlement between the parties. On the level of financial system it will secure its stability. In the context of the conducted analysis of the jurisprudence, the most probable estimation of costs of resolving the problem of the currency mortgage loans should be at around 100 billion PLN which, on the assumption that it will be incurred for several to a dozen or so years, it is possible to bear by the banking sector without a threat of losing stability of the whole financial sector. 


\section{References}

Bednarek, M.: Reżim prawny wzorców w obrocie konsumenckim [Legal regime of the legal models in the consumer trades], in: Łętowska E. [ed.], System Prawa Prywatnego [Private Law System], Warszawa: C. H. Beck, 2013

Bojęć, T. et al: Budowanie na wynajem. Perspektywy rozwoju rynku najmu w Polsce [Building for rent. Perspectives of the development of the rental market in Poland], Warszawa: 2020 Available at: https://thinkco.pl/pl/budowane-na-wynajem-raport/, accessed: $8^{\text {th }}$ October 2021

Grebieniow, A. et al: Kredyty walutowe. Węzłowe zagadnienia [Currency loans. Nodal issues], Studia i Analizy Sądu Najwyższego [Studies and Analyses of the Supreme Court], Vol. VII, 2019

Kisiel, M.: Frankowcy zdecydowanie ruszyli do sądów. Liczba pozwów wzrosła o 148 proc. [Swissfranc borrowers went to courts. The number of litigations increased by $148 \%]$, Bankier [Banker], 2021

Available at: https://www.bankier.pl/wiadomosc/Frankowcy-zdecydowanie-ruszyli-dosadow-Liczba-pozwow-wzrosla-o-148-proc-8088600.html, accessed: $8^{\text {th }}$ October 2021

Makowska, M.: Pomiędzy interwencjonizmem państwa a wolnym rynkiem - przyczynek do dyskusji o przemianach polityki mieszkaniowej w Polsce [Between the state interventionism and the free market - a contribution to the discussion about the changes of the housing policy in Poland], Społeczeństwo i Polityka [Society and Politics], no. 4, 2013

Mroczkowski, R., Abuzywność klauzul walutowych w umowach o kredyt hipoteczny denominowany $w$ walucie obcej [Abusiveness of currency clauses in a denominated in a foreign currency mortgage loan], Gdańskie Studia Prawnicze [Gdańsk Law Studies], Vol XXXVIII, 2017

Napiórkowska-Baryła, A. et al: Sytuacja mieszkaniowa w Polsce w latach 2007-2013 w kontekście zmian demograficznych [The situation of housing in Poland in the years 2007-2013 in the context of demographic changes], Humanities and Social Sciences, no. 3, 2016

\section{Legal Acts}

Act no. 483/1997 Coll., Konstytucja Rzeczpospolitej Polskiej [Constitution of the Republic of Poland], as amended

Act no. 1740/2020 Coll., Kodeks cywilny [Civil Code], as amended

Act no. 1896/2020 Coll., Prawo bankowe [Banking Law], as amended

Act no. 229/2017 Coll. o ochronie konkurencji i konsumentów [on Competition and Consumer Protection]

Act no. 154/2021 Coll. o Sądzie Najwyższym [on the Supreme Court]

Council Directive 93/13/EEC 95/1993 w sprawie nieuczciwych warunków w umowach konsumenckich [on unfair terms in consumer contracts]

\section{Court Rulings}

Polish Supreme Court ruling in case II CRN 289/76.

Polish Supreme Court ruling in case II CKN 2/91

Polish Supreme Court ruling in case V CKN 769/00

Polish Supreme Court ruling in case II CSK 625/08

Polish Supreme Court ruling in case I CSK 66/11

Polish Supreme Court ruling in case I CSK 372/11

Polish Supreme Court ruling in case V CSK 362/12

Polish Supreme Court ruling in case II CSK 517/13

Polish Supreme Court ruling in case II CSK 768/14

Polish Supreme Court ruling in case I CSK 798/15

Polish Supreme Court ruling in case II CSK 541/16

Polish Supreme Court ruling in case II CSK 803/16

Polish Supreme Court ruling in case II CSK 29/17

Polish Supreme Court ruling in case II CSK 632/17

Polish Supreme Court ruling in case III CSK 159/17

Polish Supreme Court ruling in case I CSK 242/18

Polish Supreme Court ruling in case V CSK 382/18

Polish Supreme Court ruling in case III CZP 11/20 
Polish Supreme Court ruling in case III CZP 6/21

Administrative Court in Białystok ruling in case I ACa 635/19

District Court in Warszawa ruling in case XXV C 1669/2016

District Court in Warszawa ruling in case II C 485/17

District Court in Warszawa ruling in case XXV C 2576/18

Regional Court in Warszawa-Śródmieście ruling in case VI C 1340/17

Regional Court in Warszawa-Śródmieście ruling in case I C 985/2017

European Union Court of Justice ruling in case C-243/08

European Union Court of Justice ruling in case C-618/10

European Union Court of Justice ruling in case C-472/11

European Union Court of Justice ruling in case C-397/11

European Union Court of Justice ruling in case C-488/11

European Union Court of Justice ruling in case C-377/14

European Union Court of Justice ruling in case C-154/15

European Union Court of Justice ruling in case C-118/17

European Union Court of Justice ruling in case C-260/18

European Union Court of Justice ruling in case C-419/18

European Union Court of Justice ruling in case C-511/17

European Union Court of Justice ruling in case C-452/18

European Union Court of Justice ruling in case C-19/20

\section{Other Official Documents}

Financial Stability Committee: Information on Activities of the Financial Stability Committee of $5^{\text {th }}$ December 20216

Available at: https://www.nbp.pl/nadzormakroostroznosciowy/komunikaty/2016-1205.aspx, accessed: $4^{\text {th }}$ July 2021

Financial Stability Committee: resolution no. 14/2017, w sprawie rekomendacji dotyczącej restrukturyzacji portfela kredytów mieszkaniowych w walutach obcych [on the recommendation concerning restructuring of the portfolio for the housing loans in foreign currencies]

Available

at: https://www.nbp.pl/nadzormakroostroznosciowy/podstawa/uchwala_ksfm_14_13-012017.pdf, accessed: $30^{\text {th }}$ July 2021

Komitet Stabilności Finansowej, Uchwała Nr 14/2017 z dnia 13 stycznia 2017 r. w sprawie rekomendacji dotyczącej restrukturyzacji portfela kredytów mieszkaniowych w walutach obcych"

Available at: uchwala_ksfm_14_13-01-2017.pdf [nbp.pl], accessed: 30 th July 2021

Ministry of Development: Raport. Stan mieszkalnictwa [Report. The Housing Situation], Warszawa: 2020

Available at:

https://www.gov.pl/web/rozwoj-technologia/raport-o-stanie-mieszkalnictwa, accessed: $31^{\text {st }}$ March 2021

Council of Ministers: Resolution 115/2016 on Narodowy Program Mieszkaniowy [National Housing Programme]

UKNF, Potencjalny wpływ zmian otoczenia prawnego na portfel mieszkaniowych kredytów walutowych związanych z kursem CHF [Potential effect of the changes of the legal surrounding on the portfolio of currency housing loans related to the exchange rate of CHF], Warszawa: 2021

Available

at: https://www.knf.gov.pl/knf/pl/komponenty/img/Wplyw_zmian_otoczenia_prawnego_na_por tfel_mieszkaniowych_kredytow_CHF_72739.pdf, accessed: 30 ${ }^{\text {th }}$ March 2021

\section{Internet Resources}

Heritage Real Estate Think Tank: Ile mieszkań brakuje w Polsce? Raport [How many dwellings are lacking in Poland? Report], Warszawa: 2018

Available at: 
https://heritagere.pl/wp-content/uploads/2018/12/HRE-TT-RAPORT-ILE-

MIESZKA\%C5\%83-BRAKUJE.pdf, accessed: 31 ${ }^{\text {st }}$ March 2021.

Kancelaria Votum Robin Lawyers: 90\% wygranych Frankowiczów w lutym 2020 r. [90\% Swiss-franc borrowers won in February 2020]

Available at:

https://votum-rl.pl/90-wygranych-spraw-przez-frankowiczow-w-lutym-2020-r/, accessed: $15^{\text {th }}$ July 2021.

MK: PKO BP rusza z frankowymi ugodami [PKO BP start a Swiss-Franc Settlement Programme], Bankier [Banker]

Available at: https://www.bankier.pl/wiadomosc/PKO-BP-rusza-z-frankowymi-ugodami8199079.html, accessed: $8^{\text {th }}$ October 2021.

Seb.Osz.: Jastrzębski: KNF proponuje bankom zawieranie z klientami ugód ws. kredytów frankowych [Jastrzębski: Polish Financial Supervision Authority suggests banks concluding settlments concerning the CHF loans], Bankier [Banker] 2020

Available at: https://www.bankier.pl/wiadomosc/Jastrzebski-KNF-proponuje-bankomzawieranie-z-klientami-ugod-ws-kredytow-frankowych-8016744.html, accessed: $8^{\text {th }}$ October 2021 